\title{
PREDICTING THE ADOPTION OF E-LEARNING MANAGEMENT SYSTEM: A CASE OF SELECTED PRIVATE UNIVERSITIES IN NIGERIA
}

\author{
Dr. Olanike Sharon NICHOLAS-OMOREGBE \\ College of Business and Social Sciences \\ Covenant University \\ Ota, Nigeria \\ Dr. Ambrose Agbon AZETA \\ College of Science and Technology \\ Covenant University \\ Ota, Nigeria \\ Dr. Idowu Aigbovo CHIAZOR \\ College of Business and Social Sciences \\ Covenant University \\ Ota, Nigeria \\ Dr. Nicholas OMOREGBE \\ College of Science and Technology \\ Covenant University \\ Ota, Nigeria
}

\section{ABSTRACT}

Despite the availability of studies on e-learning management system (eLMS) using information system models, its theoretical foundations have not yet captured social constructs that are peculiar to developing countries including Nigeria. This study was undertaken with the aim of investigating factors that could influence eLMS adoption in higher education. Drawing upon the Social Learning Theory (SLT), Unified Theory of Acceptance and Use of Technology (UTAUT), and two other variables which are Technology Culturation and Power (electricity), an empirical based model was developed to identify predictors of eLMS. The study used Smart Partial LeastSquare-Structured Equation Modeling (PLS-SEM) to examine the pattern of inter-correlation among the SLT and UTAUT constructs. The survey method of research was used by administering questionnaires to undergraduate students of 3 selected private universities in Ogun state, Nigeria with a sample size of $\mathbf{4 7 2}$. The results show that Attitude, Social Influence and Technology Culturation are strong determining factors of intention to adopt eLMS, while Performance Expectancy and Power do not significantly influence the Behavioural Intention to adopt eLMS. More so, Performance Expectancy and Behavioural Intention have positive influence on student grades. The results of this study will provide theoretical information on the intention to adopt eLMS and should be of interest to both researchers and education administrators in terms of planning and decision making.

Keywords: e-Learning management system, SLT, UTAUT, PLS-SEM, technology culturation and power, Nigeria. 


\section{INTRODUCTION}

E-learning could be defined as the utilization of technologies or electronic devices such as desktop/laptop computers, CD/DVD players, smart phones, and other modern day tools, to enhance traditional face-to-face method of learning (Abuhamdeh, 2010; Ahmad, 2012). It is the use of electronic educational technology in learning and teaching to enhance and support the process of knowledge dissemination (Oye, Salleh \& Lahad, 2011; Azeta et al., 2009). E-learning ensures effective pedagogy and curriculum implementation in the computer age (Ajadi, Salawu, and Adeoye, 2008). With advancement in digital technologies, institutions are progressively searching for the potential utilization of information and communication technologies (ICT) to facilitate flexible teaching needs (Nanayakkara, 2007; Sihar, Aziz, \&Suleiman, 2011). Inspite of the proliferation of ICT and benefits of e-Learning Management System (eLMS) in most developing countries, its effective use and operation has been a major concern to stakeholders.

Many studies have examined models in adopting technologies that aid in understanding and predicting users' adoption and usage pattern (Lin, Lu \& Liu, 2013). It is essential to investigate students' perceptions of eLMS at the initial step of implementing eLMS in universities. Hence,the necessity to carry out research that recongnises the factors university students consider significant in the use and acceptance of elearning platforms.

e-Learning Management System (eLMS) is also known as Course Management Systems (CMS), and the two terms may be used interchangeably. Many universities have already adopted CMS and some others are planning on introducing CMS software such as Moodle or Blackboard to support their learning operations. However, currently, there has not been much research to explore the influence of Power (electricity) on the use of CMS. To this end, it is vital to learn its perceived usefulness from the perspectives of students. The results of this study could help universities and by extension, higher institutions make better investment decisions and help instructors in using this technology more effectively. Additionally, it can help designers of course management software to improve the learning tools and get higher satisfaction level in the learning environment (Marchewka, Liu \&Kostiwa, 2007).

The purpose of this research is to study students' acceptance of eLMS in three private universities in Ogun State, Nigeria. The Social Learning Theory (SLT) and Unified Theory of Acceptance and Use of Technology (UTAUT) were engaged to identify the factors that significantly influence the Behavioural Intention to use eLMS. The seven factors investigated include Performance Expectancy, Attitude, Social Influence, Technology Culturation, Power, Behavioural Intention and Student Grades. Smart Partial Least Square-Structured Equation Modeling (PLS-SEM) was used to analyze and examine the pattern of inter-correlation among the seven constructs. PLS-SEM has been embraced by researchers for its ability to model latent variables, measurement errors, and estimate parameters of entire theories simultaneously(Dijkstra\&Henseler, 2015).

The remaining part of this paper are structured as follows: Section two presents the literature review by examining related works on theories and model for predicting the acceptance of new technologies. The third section describes the proposed research model and hypothesis development. The fourth section highlights the research methodology. Section five presents the data analysis, and measurement for model reliability and validity. Hypothesis testing and discussion of results are contained in section six. Section seven concludes the paper.

\section{LITERATURE REVIEW}

Many institutions use eLMS as their platform to conduct fully online courses (Hsu, 2012). Examples of eLMS includes Moodle, Blackboard, WebCT, and a lot more. Moodle is a wellknown Course Management System (CMS) or eLMS. Moodle, in fact, has become very 
popular among educators around the world because of its easiness and economy. Blackboard is a course management software application that is used in higher insitituions of learning. It has quite a number of learning tools that includes online discussion board, a course calendar, information announcement, course content management, electronic mail, reviews, navigation tools, access control, grade maintenance and distribution, student progress tracking, auto marked quizzes and exams, etc. (Hutchins, 2001;Marchewka, Liu\&Kostiwa, 2007).

According to Ellis (2009), a robust LMS should contain several functions such as automation of administrative activities, self-service and self-guided services, rapid assembly and delivery of learning content, a scalable web-based platform, portability and standard support, and knowledge reuse. Moodle has all the aforementioned features.

The common features of any education learning management system include: (i) Content management, (ii) Assessment and testing, (iii) Curriculum planning, (iv) Reports generation, (v) Communication and collaboration, (vi) Classroom and college announcements (Kulshrestha\& Kant, 2013). A learning management system for educational background should be able to do the following: (i) centralized and automate administration, (ii) self service and guided services, (iii) Speed in assembling and delivery of learning content, (iv) Integrated training initiatives on a web platform, (v) support for portability and standards, and (vi) content personalization and knowledge reusability feature (Sharma \&Vatta, 2013).

\section{Related Works}

The literature in the individual acceptance and use of information systems recognizes different technologies acceptance models and frameworks of factors influencing user's adoption behaviour. The four most commonly quoted models in the literature are: (i) Technology Acceptance Model (TAM) (Davis, 1993) (ii) TAM2 (Venkatesh\& Davis, 2000) (iii) The Unified Theory of Acceptance and Use of Technology (UTAUT) (Venkatesh et al, 2003) and (iv) Diffusion of Innovation (DOI) by Rogers (1983).

The survey by Claar, Dias \& Shields (2014), was carried out to measure several technology acceptance factors based on the technology acceptance model (TAM). The results supported the following relationships between the variables: Perceived Ease of Use (PE), has a significant positive influence on perceived usefulness (PU); Perceived usefulness (PU) has a significant positive influence on attitude toward using (AT); Perceived Ease of Use (PE) has a significant positive influence on attitude toward using (AT); Perceived Usefulness (PU) has a significant positive influence on Behavioral Intentions to use (BI); Attitude toward using has a significant positive influence on behavioral intentions to use.

The research by Nanayakkara (2007) investigated the factors that influence or restrain the adoption of e-learning systems in the universities, higher education institutes as well as polytechnics in New Zealand. The results revealed that while individual factors have significant contributions to the LMS adoption, the system as well as organisational factors are the most important for the acceptance of users in elearning platforms.

Lin, Lu \& Liu (2013) reviewed and assessed models of behavioral intention which includes TAM, TAM2, TPB and UTAUT. This research generated a new conceptual model to explain the effect of teaching styles and learning styles on the extent of acceptance of elearning systems. The proposed research model incorporates the above-mentioned constructs to understand system adoption more comprehensively and assesses e-learning management systems in higher education. In the study, the Education Behavioral Intention Model (EduBIM) was proposed as a new technology acceptance model.

The research by Alrawashdeh, Muhairat and Alqatawnah (2012) extended Unified Theory of Acceptance and Use Technology (UTAUT) using some factors involving flexibility of web 
based training system, system interactivity and system enjoyment, so as to explain the employees' intention to use web based training system. The results of the research by Abu-Al-Aish \& Love (2013), extends the UTAUT in the context of m-learning acceptance by adding quality of service and personal innovativeness to the structure of UTAUT and provide practitioners and educators with useful guidelines for designing a successful $\mathbf{m}$ learning system.

Based on UTAUT, the study by Maina \& Nzuki (2015) examined the influence of performance expectancy, social influence, effort expectancy and facilitating conditions on the acceptance of E-learning Management System (EMS) in institutions of higher learning in Kenya. The study found that expected performance, enabling infrastructures, institutional policies, training support and leadership and ease of use influenced the adoption of EMS in institutions of higher learning.

AlQudah (2014) applied Technology Acceptance Model's (TAM) extension to discover the attitude of staff towards Moodle. The results shows that the perceived ease of use (PEOU) is a more significant obstacle in adopting Moodle. This means that the instructors tend to use Moodle if they think Moodle is easy to use. PEOU refers to the degree to which instructors believe Moodle usage would be free of effort and it would be easy to handle.The study by Raman, Don, Khalid \&Rizuan(2014) reported performance expectancy, facilitating conditions and social influence as having significant influence on the behavioural intention to adopt Moodle.

The study by Marchewka, Liu \&Kostiwa (2007) describes student perception in terms of applying the UTAUT model. The UTAUT model combines earlier TAM related studies. Nevertheless, in this study, mixed reaction for this model was found in terms of the reliability of the scale items representing the UTAUT constructs and the hypothesized relationships. Although students tend to agree that Blackboard is good and they use it regularly, most of the software's features are not being used to their fullest capability.

Lwoga \& Komba (2014) explored the factors that predict students' continued usage intention of web-based learning management systems (LMS) in Tanzania, with special focus on the School of Business of Mzumbe University (MU). The results reveal that actual usage was determined by self-efficacy, whereas continuous usage intentions of webbased learning system was predicted by performance expectancy, social influence, effort expectancy, self-efficacy and actual usage. Challenges for using web-based LMS were related to ICT infrastructure barrier, limited skills, weak ICT policies, LMS user interface was not user friendly, management and technical support, lack of awareness, lack of time to prepare e-content and use of the e-learning system and resistance to change.

To the best of our knowledge, no study has integrated the two social factor variables of Technology Culturation and Power to existing information system (IS) model (TAM, TAM2, UTAUT, DOI) to determine the level of acceptance of e-learning management system among higher institutions in Nigeria as a developing country.

\section{RESEARCH MODEL AND HYPOTHESES}

The following research questions were formulated for this study: (i) Can the UTAUT Model and SLT comprising Performance Expectancy, Social influence, Attitude, Technology Culturation, Power, Behavioural Intention and Student Grades be used to predict the acceptance of e-Learning Management System? and (ii) Will the establishment of the Behavioural Intention to adopt eLMS positively impact on student grades? The hypotheses in this section were formulated from the seven variables in the research model. 
Performance Expectancy (PE): PE is the degree to which an individual believes that using a technology will help to attain gains in task performance. It was predicted in this study that performance expectancy has a positive influence on student's behavioural intention to adopt eLMS which could impact positively on student grades. The results from the TAMbased study by AIQudah (2014) indicated that the perceived ease of use (PEOU) is a more significant barrier in adopting Moodle. Meanwhile, in the study by Maina and Nzuki (2015) and Raman et al., (2014), performance expectancy using UTAUT was discovered to influence the adoption of E-Learning Management System in institutions of higher learning. The study however considered eLMS as a general context, and was not specific on moodle, blackboard, etc. However, in this paper, SLT and UTAUT was engaged to ascertain level of relationship between performance expectancy and behavioural intention. Two Hypotheses $(\mathrm{H})$ were formulated from PE as follows:

\section{H1-Performance expectancy has a positive influence on Student grades; and \\ H2-Performance expectancy has a positive influence on behavioural intention to adopt eLMS.}

Attitudes (AT): Attitude towards using technology is an individual's overall affective reaction to using a technology. Claar, Dias\& Shields (2014) utilized the technology acceptance model (TAM) in their study and discovered that Attitude towards using has a significant positive influence on behavioral intentions to use. There is need to confirm if using UTAUT in this study, could have a positive influence on the intention to use eLMS, hence, the hypothesis:

\section{H3-Attitude towards the use of elearning has a positive influence on behavioural intention to adopt eLMS.}

Social Influence (SI): SI is the degree to which an individual perceives the pressure from others (such as friends, colleagues, teachers, parents, leaders, etc.) influence the use of a particular technology. In the study by (Raman et al., 2014; and Marchewka, Liu \&Kostiwa, 2007), significant relationship exist between social influence and behavioural intention to adopt eLMS. There was need to confirm this prediction with respect to the location (Ogun state) through this study. The relationship between social influence and eLMS was hypothesized in this study as follows:

H4-Social Influence has a positive influence on behavioural intention to adopt eLMS.

Technology Culturation (TC): TC is a concept that represents a person's prior exposure to relative technologies like television, cable satellites, video games, etc. It assumes that this can affect an individual's acceptance of other ICTs or other advanced technologies subsequently (Nicholas-Omoregbe, 2015). In corroboration, Loch et al, (2003) argues that the degree of technological culturation is seen as influencing the extent of ICTs usage within a given society. Technology Culturation is the influence of technologicallyadvanced cultures on the attitude of an individual to technology (Okoli, 2003). Recent research on usage of ICTs argues the degree of technological culturation of a society impacts the usage of a technology by that society (Loch et al, 2003). Technology Culturation is hypothesized as follows:

\section{H5-Technology Culturation has a positive influence on behavioural intention to adopt eLMS.}

Power (PO): PO is the energy that is produced by mechanical, electrical, or other means which is used to operate a device. Power, electricity and energy are often used interchangeably. According to eLAReport (2015), the problem of Nigeria is worsened by lack of adequate power. Frequent and irregular power supply in Nigeria has been a persistent problem affecting virtually all aspects of the economy, including education (Anene, et al, 2014). Chigbu and Dim (2012) reported that the problem of unsteady 
power supply is affecting technology integration in the Nigerian university. It was therefore necessary to confirm these claims with respect to the universities in Ogun State Nigeria. The relationship between power and student's behavioural intention to adopt eLMS was hypothesized as follows:

H6-Power has a positive influence on behavioural intention to adopt eLMS.

Behavioural intention (BI): BI shows the intention a user has to make use of a technology under a given behavior. It was predicted that student's behavioural intention to adopt eLMS has an encouraging influence on student grades.

H7-Behavioural Intention to adopt eLMS has a positive influence on student grades.

The proposed research model is contained in Figure 1with indicators, latent variables and hypotheses. The model integrates the Technology Culturation and Power constructs to understand the adoption of e-learning management systems in higher education more thoroughly in the socio-cultural context.The path model containing the path coefficient from variable to variable and from variable to indicators is shown in Figure 1 . The coefficient of determination, $\mathbf{R}^{2}$ for Behavioural Intention to adopt eLMS is 0.430 endogenous latent variable and Student Grades is 0.369 . This means that the five latent variables (Performance Expectancy, Attitude, Social Influence, Technology Culturation and Power) moderately explain $43.0 \%$ of the variable in Behavioural Intention. Performance Expectancy and Behavioural Intention both explains $36.9 \%$ of the variance of performance of Students Grades.

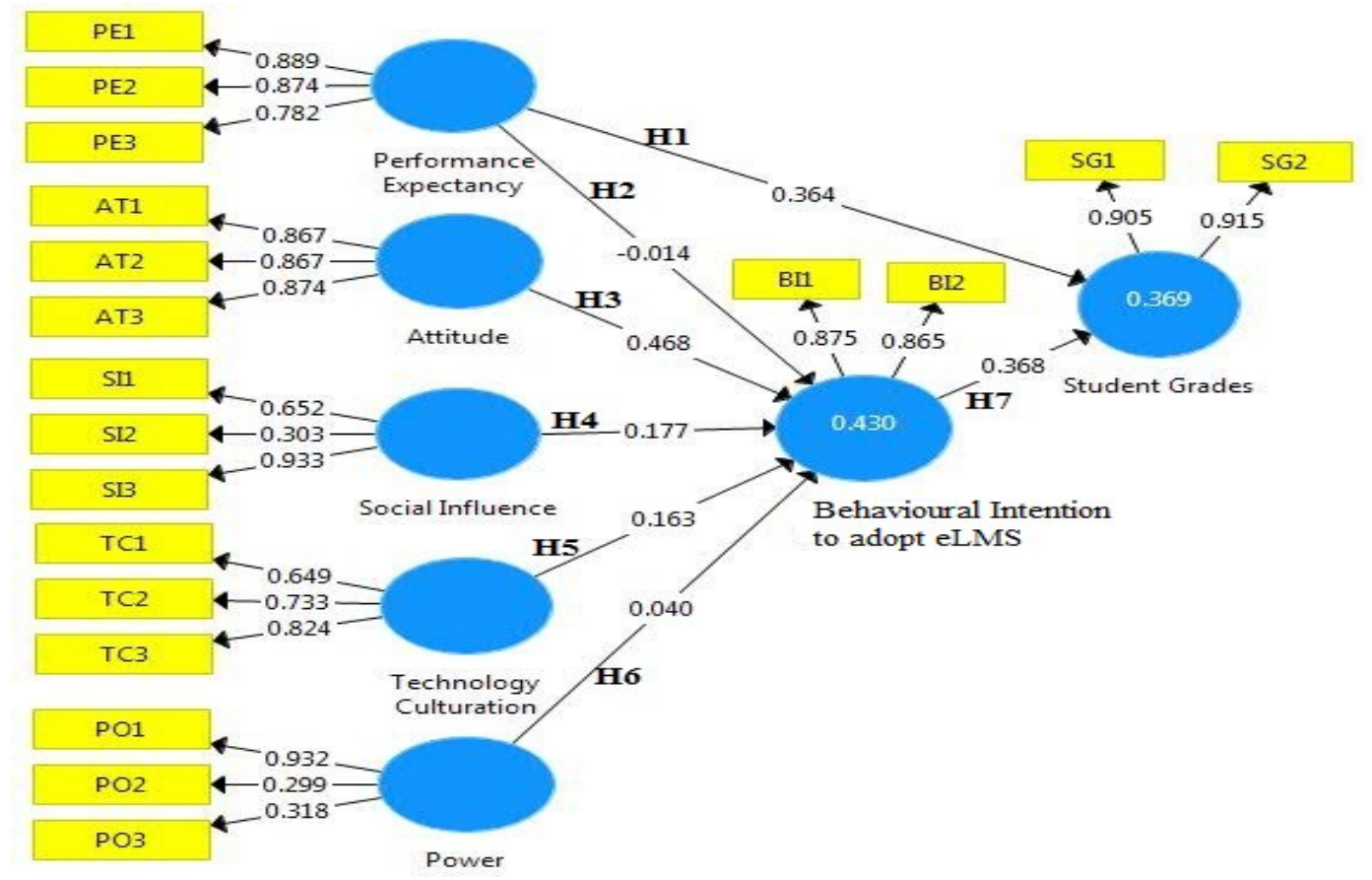

Figure 1. Research model and coefficient Source: Survey Data (2015)

\section{RESEARCH METHODOLODY}

The research design of this study uses survey method for data collection. Samples were taken from undergraduate students from three (3) universities out of the eleven (11) private universities in Ogun State, Nigeria. The method of selecting the three (3) 
universities was random sampling technique. The research instrument used was questionnaire and a sample size of $\mathbf{4 7 2}$ was considered for the study.

Data collection was conducted in the month of December, 2015. The questionnaire was structured into three parts. The first part asked questions relating to demographic details such as, gender, age, years of Internet/computer experience, eLMS in use, how many semesters they have been using eLMS. The second section investigated the factors for eLMS adoption. The section was divided into sub sections.

The section B questions on the questionnaire were based on seven variables (Performance Expectancy, Attitude, Social Influence, Technology Culturation, Power, Behavioural Intention and Student Grades). The participants were asked to rate three indicators under all the variables, except Behavioural Intention and Student Grades with two indicators. All the variables where rated on a scale from one to five, as strongly disagree, disagree, indifferent, agree, strongly agree, respectively. SmartPLS3 software was used to carry out the analysis and compute the loadings, factor loadings, $\mathbf{R}^{2}$, Average Variance Extracted (AVE), Composite Reliability, Discriminant Validity and Convergence Validity.

\section{DATA ANALYSIS}

From the analysis, gender had 118 (25\%) male and 354 (75\%) female. Respondent's ages ranged from a minimum of 15 to a maximum of 19 (with an average age of 17 years). $227(48 \%)$ of respondents between 6 and 10 years have used the Internet/Computer technology the most. The most used e-learning management system is Moodle $378(80 \%) .109(23 \%)$ said they have been using eLMS since 1 semester and $74(15.6 \%)$ said since 6 semesters. All the demographic details are in Table 1.

Table 1. Demographic Data $(\mathrm{N}=472)$

\begin{tabular}{ll}
\hline Items & Variables and Percentages \\
\hline Gender & Male $354(75 \%)$, Female $118(25 \%)$ \\
Age & $\begin{array}{l}15-19(68 \%), 20-24(32 \%), 25-29 \\
(0 \%), 30 \text { and above }(0 \%)\end{array}$ \\
Years of Internet/ Computer experience & $\begin{array}{l}0-5 \text { yrs }(47 \%), 6-10 \text { yrs (48\%), 11-15 yrs } \\
(4 \%), 16-20 \text { yrs (2\%) }\end{array}$ \\
$\begin{array}{ll}\text { Which of these learning management } \\
\text { system (LMS) is used by your school? }\end{array}$ & $\begin{array}{l}\text { Moodle(80\%), Blackboard(15\%), } \\
\text { WebCT(11), Others specify }(4 \%)\end{array}$ \\
$\begin{array}{l}\text { How many semesters have you been } \\
\text { using eLMSie Moodle, Blackboard, } \\
\text { WebCT, etc }\end{array}$ & $\begin{array}{l}1 \text { semester }(23 \%), 2 \text { semesters }(11.2 \%), \\
3 \text { semesters }(83 \%), 4 \text { semesters }(7 \%),\end{array}$ \\
\hline
\end{tabular}

Source: Survey Data (2015)

\section{Measuring Reliability and Validity}

The research model was tested for reliability and validity. A stable estimation was obtained given that the reliability test algorithm converged before reaching the maximum number of iterations. The algorithm converged only after 12 iterations (against the maximum number of 300 , set as default in smartPLS), so the estimation is good. It is 
important to establish the reliability as well as validity of the latent variables so as to complete the examination of the structural model. Table 2 shows the various reliability and validity items reported using smart PLS-SEM.

Table 2. Reliability and validity items

\begin{tabular}{llllll}
\hline $\begin{array}{l}\text { Latent } \\
\text { Variables }\end{array}$ & Indicators & Loadings & $\begin{array}{l}\text { Indicator } \\
\text { reliability }\end{array}$ & $\begin{array}{l}\text { Composite } \\
\text { reliability }\end{array}$ & AVE \\
\hline $\begin{array}{llll}\text { Performance } \\
\text { Expectancy }\end{array}$ & PE1 & 0.889 & 0.790 & 0.886 & 0.721 \\
& PE3 & 0.874 & 0.764 & & \\
Attitude & AT1 & 0.782 & 0.612 & & \\
& AT2 & 0.867 & 0.752 & 0.903 & 0.755 \\
& AT3 & 0.874 & 0.752 & & \\
Social & SE1 & 0.652 & 0.425 & 0.689 & 0.463 \\
Influence & SE2 & 0.303 & 0.092 & & \\
& SE3 & 0.933 & 0.870 & & \\
Technology & TC1 & 0.649 & 0.421 & 0.781 & 0.545 \\
Culturation & TC2 & 0.733 & 0.537 & & \\
& TC3 & 0.824 & 0.679 & & \\
Power & PO1 & 0.932 & 0.869 & 0.553 & 0.353 \\
& PO2 & 0.299 & 0.089 & & \\
& PO3 & 0.318 & 0.101 & & \\
Behavioural & BI1 & 0.875 & 0.766 & 0.862 & 0.757 \\
Intention & BI2 & 0.865 & 0.748 & & \\
Student & SG1 & 0.905 & 0.819 & 0.906 & 0.828 \\
Grades & SG2 & 0.915 & 0.837 & & \\
\hline
\end{tabular}

Source: Survey Data (2015)

From Table 2, the composite reliability values are shown to be larger than $\mathbf{0 . 6}$ for all the latent variables (except Power with 0.553), so high levels of internal consistency reliability has been demonstrated among all seven reflective latent variables (Bagozzi\& Yi, 1988;Hair et al., (2012). To check convergent validity, each latent variable's Average Variance Extracted (AVE) is evaluated. It was found that all of the AVE values are greater than the acceptable threshold of 0.5 (except power with 0.353 ), so the convergent validity is confirmed as recommended by Bagozzi \& Yi (1988). For indicator reliability, except for SE2 (0.092), PO2 (0.089) andPO3 (0.101), each indicator score higher than 0.4 threshold recommended for exploratory research (Hulland, 1999). This indicates that more than $75 \%$ of the indicators are reliable.

Table 3 shows the discriminant validity indicating that the value on top of each row is larger than other values in the column and its row, according to the theory in Fornell \& Larcker (1981). Similar observations are made for all latent variables. The result shows that discriminant validity is well established. 
Table 3. Discriminant validity

\begin{tabular}{|c|c|c|c|c|c|c|c|}
\hline & Attitude & $\begin{array}{l}\text { Behavioural } \\
\text { Intention }\end{array}$ & $\begin{array}{l}\text { Performance } \\
\text { Expectancy }\end{array}$ & Power & $\begin{array}{l}\text { Social } \\
\text { Influence }\end{array}$ & $\begin{array}{l}\text { Student } \\
\text { Grades }\end{array}$ & $\begin{array}{l}\text { Technology } \\
\text { Culturation }\end{array}$ \\
\hline Attitude & 0.869 & & & & & & \\
\hline $\begin{array}{l}\text { Behavioural } \\
\text { Intention }\end{array}$ & 0.609 & 0.870 & & & & & \\
\hline $\begin{array}{l}\text { Performance } \\
\text { Expectancy }\end{array}$ & 0.593 & 0.382 & 0.849 & & & & \\
\hline Power & 0.093 & 0.171 & 0.132 & 0.594 & & & \\
\hline $\begin{array}{l}\text { Social } \\
\text { Influence }\end{array}$ & 0.386 & 0.405 & 0.362 & 0.226 & 0.680 & & \\
\hline $\begin{array}{l}\text { Student } \\
\text { Grades }\end{array}$ & 0.598 & 0.506 & 0.504 & 0.300 & 0.383 & 0.910 & \\
\hline $\begin{array}{l}\text { Technology } \\
\text { Culturation }\end{array}$ & 0.478 & 0.442 & 0.302 & 0.302 & 0.267 & 0.498 & 0.739 \\
\hline
\end{tabular}

Source: Survey Data (2015)

\section{HYPOTHESIS TESTING AND DISCUSSION OF RESULTS}

The T-statistics for significance testing of both the inner and outer model, and the results of the hypothesis testing are presented in Table 4.

Table 4. T-statistics of path coefficient (Inner model)

\begin{tabular}{|c|c|c|c|c|}
\hline Hypothesis & 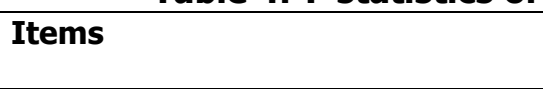 & $\begin{array}{l}\text { Path } \\
\text { Coefficient, } \beta\end{array}$ & $\begin{array}{l}\mathbf{T} \\
\text { Statistics }\end{array}$ & Remark \\
\hline H1 & $\begin{array}{l}\text { Performance Expectancy } \\
->\text { Student grades }\end{array}$ & $0.364 *$ & 9.269 & Supported \\
\hline H2 & $\begin{array}{l}\text { Performance Expectancy- } \\
\text { > Behavioural Intention }\end{array}$ & $-0.014 * *$ & 0.334 & $\begin{array}{l}\text { Not } \\
\text { Supported }\end{array}$ \\
\hline H3 & Attitude->Behavioural Intention & $0.468 *$ & 9.680 & Supported \\
\hline H4 & $\begin{array}{l}\text { Social Influence ->Behavioural } \\
\text { Intention }\end{array}$ & $0.177 *$ & 4.340 & Supported \\
\hline H5 & $\begin{array}{l}\text { Technology Culturation } \\
\text {->Behavioural Intention }\end{array}$ & $0.163 *$ & 3.585 & Supported \\
\hline H6 & Power ->Behavioural Intention & $0.040 * *$ & 0.431 & $\begin{array}{l}\text { Not } \\
\text { Supported }\end{array}$ \\
\hline H7 & $\begin{array}{l}\text { Behavioural Intention-> Student } \\
\text { grades }\end{array}$ & $0.368 *$ & 7.848 & Supported \\
\hline
\end{tabular}

$* \mathrm{p}<=0.01 ; * * \mathrm{p}>0.05 \quad$ Source: Survey Data (2015)

H1-Performance Expectancy has A Positive Influence on Student Grades

From Table 4, the path between Performance Expectancy and Student Grades was found to be significant $(\beta=0.364, p<0.01)$, thereby supporting Hypothesis 1 . 
H2-Performance Expectancy has A Positive Influence on Behavioural Intention to Adopt eLMS.

The path between Performance Expectancy and Behavioural Intention to adopt eLMS was found to be insignificant $(\beta=-0.014, p>0.05)$, thereby Hypothesis 2 was not supported. However, this result did not agree with the study of Abu-Al-Aish\& Love (2013), and that of Maina and Nzuki, (2015).

H3-Attitude towards the Use of Elearning has A Positive Influence on Behavioural Intention to Adopt eLMS.

Individual Attitude $(\beta=0.468, p<0.01)$ has a significant influence on Behavioural Intention to adopt eLMS and thereby supporting Hypothesis 3. Infact, Attitude has the strongest effect, with a path coefficient of 0.468 , giving emphasis to the important role of an individual's attitude in the use of eLMS technology. This result is similar to those found in the studies of Park (2009); Claar,(2014); Alharbi\& Drew (2014); Wichadee (2015); Teoh\& Hoe (2015); Rabaa'(2016); Adewole-Odeshi (2014); and Fidani \& Idrizi (2012). However, a prior study by Amer, Ahmad \&Jo (2013) gave a contrary result to this findings by reporting a lack of significant influence of attitude on behavioral intention to adopt eLMS.

H4-Social Influence has A Positive Influence on Behavioural Intention to Adopt eLMS.

Hypothesis 4 was found to be of high significance at $p<0.01 \quad(\beta=0.4340, p<0.01)$. (see Table 3).

H5-Technology Culturation has A Positive Influence on Behavioural Intention to Adopt eLMS.

Hypothesis 5 was found to be significant at $p<0.01,(\beta=3.585, p<0.01)($ see Table 3$)$.

H6-Power has A Positive Influence on Behavioural Intention to Adopt eLMS.

Hypothesis 6 (Influence of Power on Behavioural Intention) was not significant $(\boldsymbol{\beta}=\mathbf{0 . 0 4 0}$, p>0.05).

H7-Behavioural Intention to adopt eLMS has A Positive Influence on Student Grades.

Hypothesis 7 was found to be significant at $p<0.01$. This outcome did not agree with the study of Klobas\& McGill (2009) which found a weak relationship between Behavioural intention to adopt eLMS and students' grade.

The outer model can be explored by checking the T-statistic in the "Outer Loadings (Means, STDEV, T-Values)" window. As presented in Table 5, all of the T-Statistics variables satisfy the significant level criteria except PO2 and PO3 under Power. So, it can be concluded that the loadings are successful with nineteen out of twenty-one indicators showing significant levels in the outer model. 
Table 5. T-Statistics of outer loadings

\begin{tabular}{|c|c|c|c|}
\hline & Path Coefficient, $\boldsymbol{\beta}$ & T Statistics & Remarks \\
\hline AT1 <- Attitude & $0.867 *$ & 64.623 & Supported \\
\hline AT2 <- Attitude & $0.867 *$ & 63.972 & Supported \\
\hline AT3 <- Attitude & $0.874 *$ & 44.602 & Supported \\
\hline BI1 <- Behavioural Intention & $0.875 *$ & 45.614 & Supported \\
\hline BI2 <- Behavioural Intention & $0.865 *$ & 53.648 & Supported \\
\hline PE1<- Performance Expectancy & $0.889 *$ & 70.486 & Supported \\
\hline PE2 <- Performance Expectancy & $0.874 *$ & 64.336 & Supported \\
\hline PE3 <- Performance Expectancy & $0.782 *$ & 26.489 & Supported \\
\hline P01 <- Power & $0.932 * *$ & 2.112 & Supported \\
\hline PO2 <- Power & $0.299 * * *$ & 0.970 & Not supported \\
\hline P03 <- Power & $0.318 * * *$ & 1.075 & Not supported \\
\hline SG1 <- Student Grades & $0.905 *$ & 55.239 & Supported \\
\hline SG2 <- Student Grades & $0.915 *$ & 85.033 & Supported \\
\hline SI1 <- Social Influence & $0.652 *$ & 8.136 & Supported \\
\hline SI2 <- Social Influence & $0.303 *$ & 2.938 & Supported \\
\hline SI3 <- Social Influence & 0.933* & 33.929 & Supported \\
\hline TC1 <- Technology Culturation & $0.649 *$ & 10.680 & Supported \\
\hline TC2 <- Technology Culturation & 0.733* & 18.206 & Supported \\
\hline TC3 <- Technology Culturation & $0.824 *$ & 30.209 & Supported \\
\hline
\end{tabular}

\section{THEORETICAL IMPLICATIONS AND PRACTICAL SIGNIFICANCE OF THE STUDY}

The two research questions were provided with their respective answers in this study. For the first research question, not all the UTAUT factors and one SLT factor of Attitude considered in this study have positive influence on the Behavioural Intention to adopt eLMS. Attitude, Social Influence and Technology Culturation all have significant influence on behavioural intention to adopt eLMS, whereas Performance Expectancy and Power does not have significant influence on the behavioural intention to adopt eLMS.Therefore, the prediction of expected performance of a technology among the selected universities in Ogun State Nigeria as part of the factors that could influence the acceptance of eLMS was not supported.

Against all expectations of the Power (electricity) supply problem in Nigeria, Power was not discovered through this study as one of the factors influencing the Behavioural intention by students in universities in Ogun state to accept eLMS. One of the reasons for this outcome may be that the universities used in this study are all privately owned where things arguably works. If this study is carried out probably in public universities in Nigeria, different findings may be discovered concerning Power influence on students' acceptance of eLMS. For the second research question, the establishment of Behavioural Intention to adopt eLMS comfortably predicted a positive influence on student grades with 0.368 . This shows that the use of eLMS by students will positively influence their grades. However, this result was somewhat not in agreement with that of Klobas\& McGill (2009), which found a weak influence of eLMS on students' grade. 


\section{Limitations of Current Study and Further Research}

The main limitation of this study is premised on the fact that only three (3) private universities were considered in the survey out of eleven (11) private universities in Ogun State, Nigeria. Extending the scope to include public universities in Ogun State where we have the highest concentration of Universities in Nigeria is being suggested for further studies.

\section{CONCLUSION}

This study uses SLT and UTAUT to determine users acceptance of adopting eLMS among universities in Ogun State, Nigeria. Two social factor variables - Technology Culturation and Power were integrated with some existing factors of SLT and UTAUT to determine their significant relationship with Behavioural Intention to adopt eLMS. Findings from this research show that Performance Expectancy and Power have no significant influence on Behavioural Intention to use eLMS. Largely, the analysis of the survey results concludes that with the exception of few items, majority of the elements that have been recognized in the proposed model have a significant influence over user acceptance of e-learning management systems. The report from the study will assist stakeholders in planning, implementation and taking investment decisions on elearning systems.

\section{BIODATA and CONTACT ADDRESSES of AUTHORS}

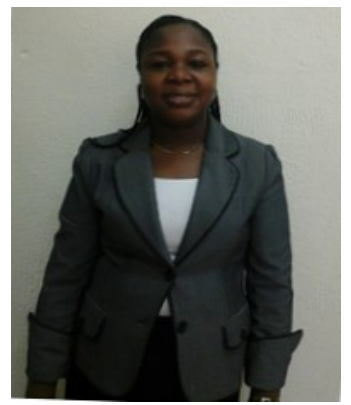

Dr. Olanike Sharon NICHOLAS-OMOREGBE has completed her PhD program in Covenant University. Her research interest areas include Sociology of Education, Sociology of Technology, and Industrial Sociology. She has over fourteen years of teaching experience in tertiary institutions. She also has scholarly publications in reputable local and international journal outlets. Additionally, she has published a few books.

Olanike Sharon NICHOLAS-OMOREGBE

Department of Mass Communication

Covenant University, Ota Ogun State, NIGERIA

Phone: + 2348032411218

Email: sharon.nomoregbe@covenantuniversity.edu.ng

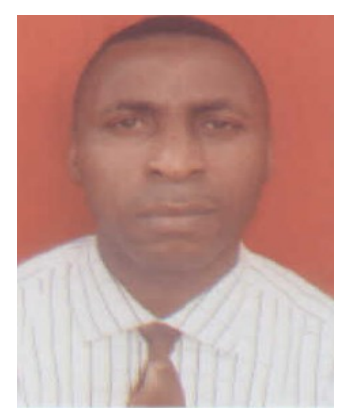

Dr. Ambrose Agbon AZETA is a Senior Lecturer in the Department of Computer and Information Sciences, Covenant University, Ota, Ogun State, Nigeria. He holds B.Sc, M.Sc and Ph.D in Computer Science from University of Benin, University of Lagos and Covenant University Nigeria respectively. He has worked and held several Information Technology (IT) positions in the industry before joining academics in 2005. His current research interests are in the following areas: Technology-Enhanced Learning, Dialogue Systems (Voice-Enabled Systems), Web/Mobile Computing and Software Engineering. He is a member of the Nigerian Computer Society (NCS) and Computer Professional Registration Council of Nigeria (CPN).

Ambrose Agbon AZETA (Ph.D)

Department of Computer and Information Sciences

Covenant University, Ota Ogun State, NIGERIA

Phone: + 2348039540844

Email: ambrose.azeta@covenantuniversity.edu.ng 


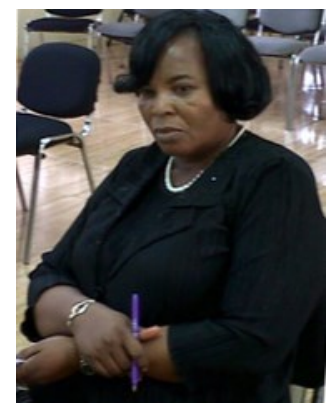

Dr. Idowu Aigbovo CHIAZOR is a Senior Lecturer in the Department of Sociology. Her area of interest is in Sociology of Development and Gender Studies. She is a strong advocate for women's rights and empowerment as enshrined in the United Nation's CEDAW Article. Dr. Chiazor had 24 years cognate cooperate experience before joining Covenant University in 2007. She has a B.Sc. M.Sc. and Ph.D degrees in Sociology of Development. Her hobbies include mentoring, charity works and Evangelism.

Idowu Aigbovo CHIAZOR, ( PhD)

Department of Sociology, Covenant University, Ota, NIGERIA

Phone: +234 8027288651

E-mail: idowu.chiazor@covenantuniversity.edu.ng

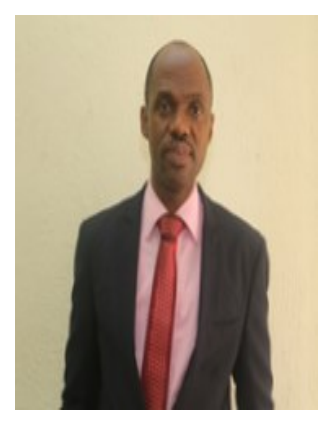

Dr. Nicholas OMOREGBE holds a PhD in Computer Science from Covenant University. He has over 70 scholarly publications in reputable academic journals and conferences covering subjects ranging from ICT diffusion, information systems design, mobile health systems, multimedia technologies to elearning. Prof. Omoregbe has more than twenty years of professional experience in Information Technology consulting. He has as well taught in tertiary institutions for over 10 years. He leads a research cluster in Software Engineering, Modelling and Intelligent Systems Research at Covenant University.

Nicholas OMOREGBE (Ph.D)

Department of Computer and Information Sciences

Covenant University, Ota Ogun State, NIGERIA

Phone: +234 8060093448

Email: nicholas.omoregbe@covenantuniversity.edu.ng

\section{REFERENCES}

Abuhamdeh, M. (2010). A hierarchical framework to quantitatively evaluate success factors of mobile learning. Unpublished PhD Thesis, Univ. of Banking and Financial Sciences, Amman, Jordan.

Abu-Al-Aish, A., \& Love, A. (2013). Factors influencing students' acceptance of $\mathbf{m}$ learning:An investigation in higher education. The International Review of Research in Open and Distance Learning, 14 (5): 82-107.

Adewole-Odeshi, E. (2014). Attitude of Students Towards E-learning in SouthWest Nigerian Universities: An Application of Technology Acceptance Model. Library Philosophy and Practice (e-journal).

Ahmad, S. A. (2012). Essentialities for E-learning: The Nigerian tertiary institutions in question. Academic Research International, 2(2): 286-291.

Ajadi, T.O., Salawu, I. O. \&Adeoye, F.A. (2008). E-learning and distance education in Nigeria. The Turkish Online Journal of Educational Technology (TOJET), 7 (4): 6170. 
Alrawashdeh, T. A., Muhairat, M.I. \&Alqatawnah, S. M. (2012). Factors affecting acceptance of web-based training system: using extended UTAUT and structural equation modeling. International Journal of Computer Science, Engineering and Information Technology(IJCSEIT), 2 (2): 45.

AlQudah, A. A. (2014). Accepting Moodle by academic staff at the university of Jordan: Applying and extending TAM in technical support factors, 10 (18): 183-200.

Alharbi, S. \& Drew, S. (2014). Using the Technology Acceptance Model in understandingacademics' behavioural intention to use Learning Management Systems. (IJACSA) International Journal of Advanced Computer Science and Applications, 5 (1), 201.

Amer, A., Ahmad A., \& Jo, S.(2013). Exploring students acceptance of e-learning usingTechnology Acceptance Model in Jordanian universities. International Journal of Education and Development using Information and Communication Technology (IJEDICT), 2013, Vol. 9, Issue 2, pp. 4-18

Anene, J., H. Imam \& Odumuh, T. (2014). Problem and prospect of e-learning in Nigerianuniversities. International Journal of Technology and Inclusive Education (IJTIE), 3 (2): 320-327.

Azeta A. A., Ayo C. K., Atayero A. A. \& Ikhu-Omoregbe N. A. (2009). A Case-Based Reasoning Approach for Speech-Enabled e-Learning System, 2nd IEEE International Conference on Adaptive Science \& Technology (ICAST). December 14 - 16, 2009, Accra Ghana. ISBN: 978-1-4244-3523-4, ISSN: 0855-8906. PP. 211-217

Bagozzi, R., \& Yi, Y. (1988). On the evaluation of structural equation models. Journal of the Academy of Marketing Science, 16(1): 74-94.

Chigbu, E.D.,\& Dim, C.L. (2012). Connectivity and accessibility in Nigerian university libraries: asurvey of access, usage, and problems in the University of Nigeria, Nsukka. Library Philosophy and Practice, 83.

Claar, C., Dias, L.,\& Shields, R. (2014). Student acceptance of learning management systems:a study on demographics. Issues in Information Systems, 15 (1): 409417.

Claar, C. (2014). Student Acceptance of Learning Management Systems: A Study on Demographics. Issues in Information Systems, 15 (1), 409-417.

Davis, F. D. (1993). User acceptance of information technology: system characteristics, user perceptions and behavioral impacts. Int. J. Man-Machine Studies, 38 (3): 475-487.

Dijkstra, T. K.,\&Henseler, J. (2015). Consistent partial least squares path modeling. MIS Quarterly. 39 (2): 297-316.

Fidani, A., \& Idrizi, F. (2012). Investigating Students' Acceptance of a Learning ManagementSystem in University Education: A Structural Equation Modeling Approach. ICT Innovations 2012 Web Proceedings, ISSN 1857-7288.

Fornell, C.,\& Larcker (1981). Evaluating structural equation models with unobservable variables and measurement error. Journal of Marketing Research, 18 (1): 39-50. 
Hair, J.F., Sarstedt, M., Ringle, C.M.,\& Mena, J.A. (2012). An assessment of the use of partial least squares structural equation modeling in marketing research. Journal of the Academy of Marketing Science, 40 (3): 414-433.

Hsu, H. (2012). The acceptance of Moodle: an empirical study based on UTAUT. Creative Education. 3 (8B): 44-46.

Hulland, J. (1999). Use of partial least squares (PLS) in strategic management research: a review of four recent studies. Strategic Management Journal, 20 (2): 195-204.

Hutchins, H.M. (2001). Enhancing the business communication course through WebCT, Business Communication Quarterly, 64: 87-94.

Klobas, J. E., \& McGill, T. J. (2009). A task-technology fit view of learning management systemimpact. Computers \& Education, 52 (2009) 496-508.

Kulshrestha, T., \& Kant, A. R. (2013). Benefits of Learning Management System (LMS) in Indianeducation. International Journal of Computer Science \& Engineering Technology (IJCSET).

Lin, P., Lu, H.,\& Liu, S. (2013). Towards an education behavioral intention model for elearning systems: An extension of UTAUT. Journal of Theoretical and Applied Information Technology.47 (3).

Loch, K., Straub, D.,\&Kamel, S. (2003). Diffusing the internet in the Arab world: The role aof social norms and technological culturation. IEEE Transactions on Engineering Management,50 (1): 45.

Lwoga, E.,\&Komba (2014). Understanding university students' behavioural continued intentions to use e-learning in Tanzania. Proceedings and Report of the 7th UbuntuNet Alliance Annual Conference, 167-188.

Maina, M. K. \&Nzuki, D .M. (2015). Adoption Determinants of E-learning Management System in Institutions of Higher Learning in Kenya: A Case of Selected Universities in Nairobi Metropolitan. International Journal of Business and Social Science, 6 (2).

Marchewka, J., Liu, C.,\&Kostiwa, K. (2007). An application of the UTAUT model for understanding student perceptions using course management software, Communications of the IIMA, 7 (2): 93-104.

Maina, M. K.,\&Nzuki, D.M. (2015). Adoption determinants of e-learning management system in institutions of higher learning in Kenya: A Case of selected universities in Nairobi Metropolitan. International Journal of Business and Social Science, 6 (2): 233-248.

Nanayakkara, C. (2007). A model of user acceptance of learning management systems: a study within tertiary institutions in New Zealand. International Journal of Learning, 13 (12): 223.

Okoli, J.C. (2003). Expert assessments of e-commerce in sub-saharanafrica: a theoretical model of infrastructure and culture for doing business using the internet. Unpublished PhD Thesis, Faculty of the Louisiana State Univ. and A and M College. 
Oye, N.D., Salleh, M. \& Iahad, N.A. (2011). Challenges of e-learning in Nigerian university education based on the experience of developed countries. International Journal of Managing Information Technology (IJMIT) 3(2): 39-48.

Park, S. Y. (2009). An analysis of the Technology Acceptance Model in understanding university students' behavioral intention to use e-learning. Educational Technology \& Society, 12 (3), 150-162.

Rabaa'I, A. A. (2016). Extending the Technology Acceptance Model (TAM) to assess students' behavioural intentions to adopt an e-Learning system: The case of Moodle as a learning tool. Journal of Emerging Trends in Engineering and Applied Sciences (JETEAS), 7(1): 13- 30 .

Raman A., Don, Y., Khalid, R. \&Rizuan, M. (2014). Usage of learning management system (Moodle) among postgraduate students: UTAUT model. Asian Social Science, 10 (14): 186.

Rogers, E. M. (1983). Diffusion of innovations (3rd ed.). New York: Free Press.

Sharma, A. \&Vatta, S. (2013). Role of Learning Management Systems in education. International Journal of Advanced Research in Computer Science and Software Engineering. 3 (6).

Survey Data (2015). A compilation from the data set gathered by the researchers. December, 2015. (Unpublished)

Teoh, K. \& Hoe, L. S. (2015). Emotion Based LMS: An investigation of user perceptions and attitudes. International Journal of Learning and Teaching, 1 (2).

Venkatesh, V.,\& Davis (2000). A theoretical extension of the technology acceptance model:Four longitudinal field studies. Management Science, 46 (2): 186.

Venkatesh, V., Morris, M., Davis, G., \& Davis, F. (2003). User acceptance of information technology: Toward a unified view. MIS Quatlerly, 27 (3): 425-478.

Wichadee, S. (2015). Factors related to faculty members' attitude and adoption of a learning management system. TOJET: TheTurkish Online Journal of Educational Technology, 14 (4). 